\title{
Effect of level of feed intake and Fusarium- contaminated wheat on rumen fermentation in cows
}

\author{
K. Matthäus ${ }^{1}$, P. Lebzien and S. Dänicke \\ Institute of Animal Nutrition, Federal Agricultural Research Centre (FAL) \\ Bundesallee 50, D-38116 Braunschweig, Germany
}

\begin{abstract}
To study the effects of level of intake on ruminal fermentation, 14 dairy cows equipped with ruminal and duodenal cannulas were fed different amounts of the same diet. The diet consisted of $60 \%$ concentrate including 55\% wheat (Fusarium-contaminated and control) and $40 \%$ maize- and grass silage (on DM-basis). Each cow was fed contaminated and control wheat. Rumen fermentation was not significantly influenced by the contamination, however the increased feed intake decreased $\mathrm{pH}$, fermentation of organic matter (FOM), of protein and of neutral detergent fibre. Efficiency of microbial protein synthesis ( $\mathrm{g}$ MP/kg FOM) was not linearly related to level of intake.
\end{abstract}

KEY WORDS: cow, rumen fermentation, level of feed intake, mycotoxins

\section{INTRODUCTION}

A high passage rate as a result of increased feed intake can decrease the ruminal digestibility of nutrients (Tyrrell and Moe, 1975) and the metabolization rate of mycotoxins, but increase the efficiency of the microbial protein synthesis (Sniffen and Robinson, 1987).

In most experiments increasing feed intake involved a higher concentrate portion in the ration. Then effects of roughage:concentrate can not be separated from effects of level of intake. Hence, the objective of the present study was to investigate the coherence between varying levels of feed intake on ruminal fermentation in cows feeding a constant ration with or without Fusariumcontamination of the wheat.

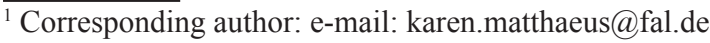




\section{MATERIAL AND METHODS}

14 dairy cows of the German Friesian breed fitted with permanent fistulas in the rumen and the proximal duodenum were used. All diets contained $60 \%$ concentrate (on DM-basis), including 55\% wheat (Fusarium-contaminated or not) and 40\% maize- and grass-silage (50:50). Dry matter (DM)-intakes ranged from 5.7 to $20.9 \mathrm{~kg} / \mathrm{d}$. Each cow was fed the concentrate with the uncontaminated and with the contaminated wheat successively.

Each experimental period consisted of three weeks for adaptation to the diets and 5 days for duodenal-sample collection. Ruminal fluid for the determination of $\mathrm{pH}$ and volatile fatty acids was sampled in the $3^{\text {rd }}$ week $3 \mathrm{~h}$ after start of morning feeding. To estimate digesta flow at the duodenum, $\mathrm{Cr}_{2} \mathrm{O}_{3}$ was used as marker. The proportion of microbial $\mathrm{N}$ of non ammonia $\mathrm{N}$ (NAN) at the duodenum was determined by NIRS (Lebzien and Paul, 1997). Fermented organic matter (FOM) was calculated by:

FOM $(\mathrm{kg} / \mathrm{d})=\mathrm{OM}$ intake $-(\mathrm{OM}$ flow at the duodenum - microbial $\mathrm{OM})$ (Microbial $\mathrm{OM}=$ microbial $\mathrm{N} \times 11.8$ )

The undegraded protein at the duodenum was estimated by subtracting endogenous protein $(\mathrm{kg} \mathrm{DM}$ at the duodenum $\mathrm{x}$ 3.6) and the microbial protein from NAN $\times 6.25$.

\section{RESULTS AND DISCUSSION}

The contents of crude nutrients and the Fusarium-toxins DON and ZON for the concentrates and silages are shown in Table 1.

Table 1. Chemical composition and mycotoxin concentrations of the feedstuffs

\begin{tabular}{|c|c|c|c|c|}
\hline \multirow[t]{2}{*}{ Parameters } & \multicolumn{2}{|c|}{ Concentrate $^{1}$} & \multirow{2}{*}{$\begin{array}{l}\text { Maize } \\
\text { silage }\end{array}$} & \multirow{2}{*}{$\begin{array}{l}\text { Grass } \\
\text { silage }\end{array}$} \\
\hline & mycotoxin period & control period & & \\
\hline Dry matter, $\mathrm{g} / \mathrm{kg}$ & 877 & 885 & 395 & 314 \\
\hline \multicolumn{5}{|l|}{ Nutrients, $g / \mathrm{kg} \mathrm{DM}$} \\
\hline organic matter & 945.6 & 944.0 & 960.1 & 875.1 \\
\hline crude protein & 207.5 & 209.5 & 76.1 & 137.4 \\
\hline crude fibre & 66.0 & 66.7 & 174.7 & 312.9 \\
\hline neutral detergent fibre & 221.8 & 225.8 & 404.0 & 543.2 \\
\hline \multicolumn{5}{|l|}{ Mycotoxins } \\
\hline deoxynivalenol, mg/kg DM & 5.2 & 0.1 & 0.6 & $<\mathrm{DL}^{2}$ \\
\hline zearalenone, $\mu \mathrm{g} / \mathrm{kg} \mathrm{DM}$ & 59.4 & 21.7 & 62.4 & 2.0 \\
\hline
\end{tabular}


Increased feed intake significantly decreased the ruminal $\mathrm{pH}(\mathrm{P}<0.001$; Figure 1).

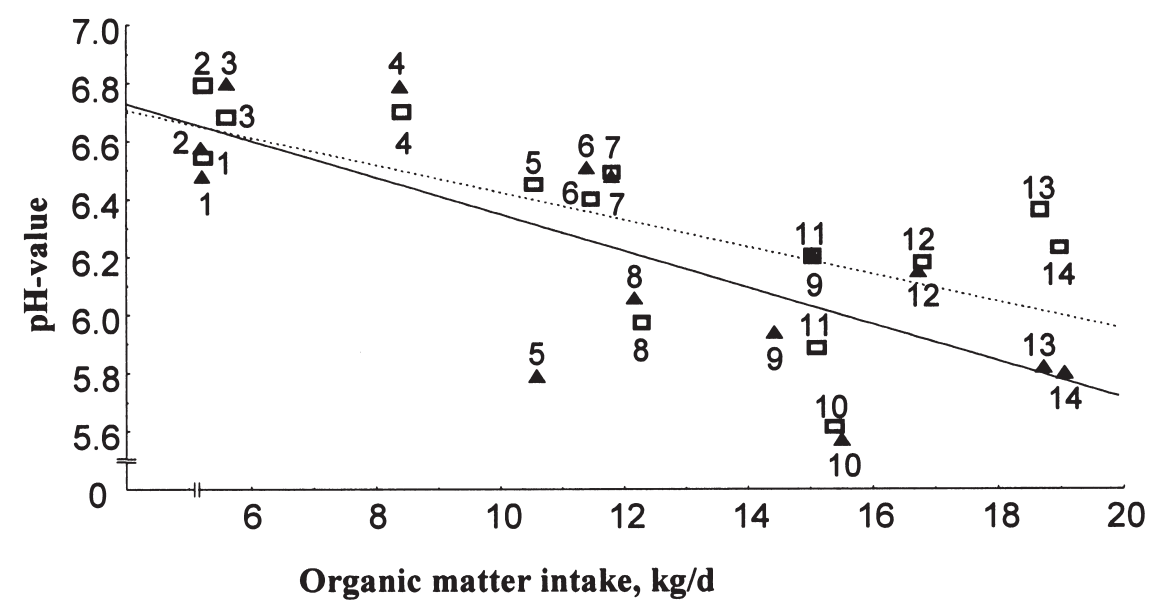

Figure 1. pH-value in rumen fluid (collected $3 \mathrm{~h}$ after morning feeding) in dependence on the organic matter intake, $\cdots \square \cdots$ Control period, $\_-$Mycotoxin period, numbers denote individual cows

In accordance to Tyrell and Moe (1975) the fermented portion of organic matter decreased moderately at increased organic matter intake but there was a quite large individual variation $(\mathrm{P}<0.001$; Figure 2$)$. The most pronounced decrease was observed with regard to NDF-fermentation.

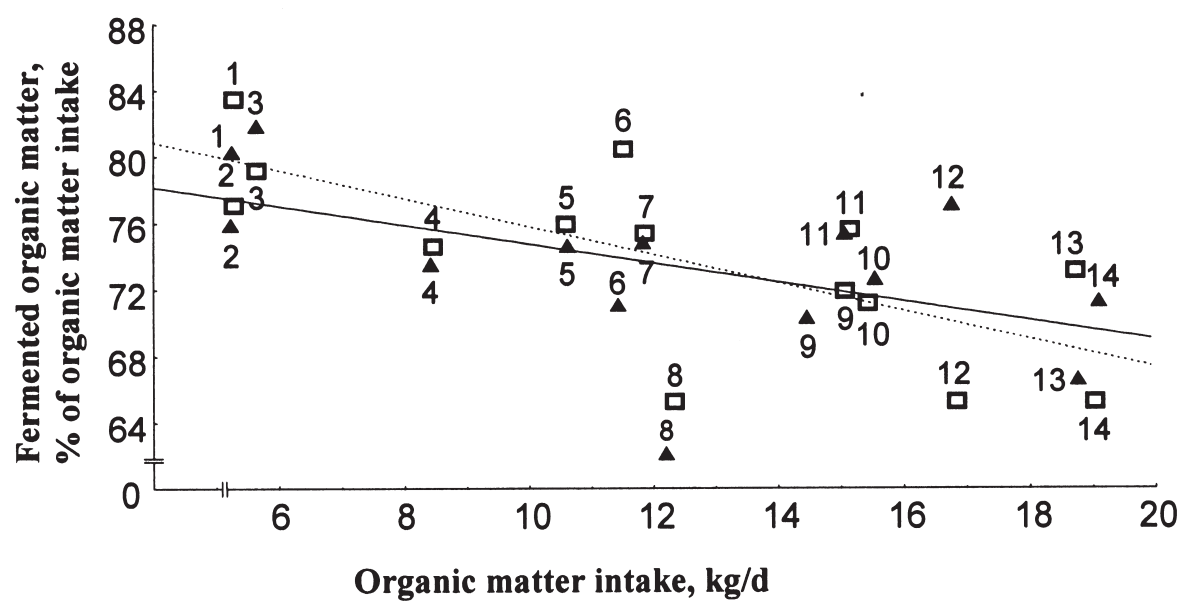

Figure 2. Fermented organic matter (\% of OM intake) in dependence on the organic matter intake, …… Control period, $-\leftarrow$ Mycotoxin period, numbers denote individual animals 
Although increasing organic matter intake significantly increased the quantities of microbial protein $(\mathrm{P}<0.001)$ and undegraded feed protein $(\mathrm{P}<0.001)$ at the duodenum, the relationship between efficiency of microbial protein synthesis and level of organic matter intake was not linear (Figure 3).

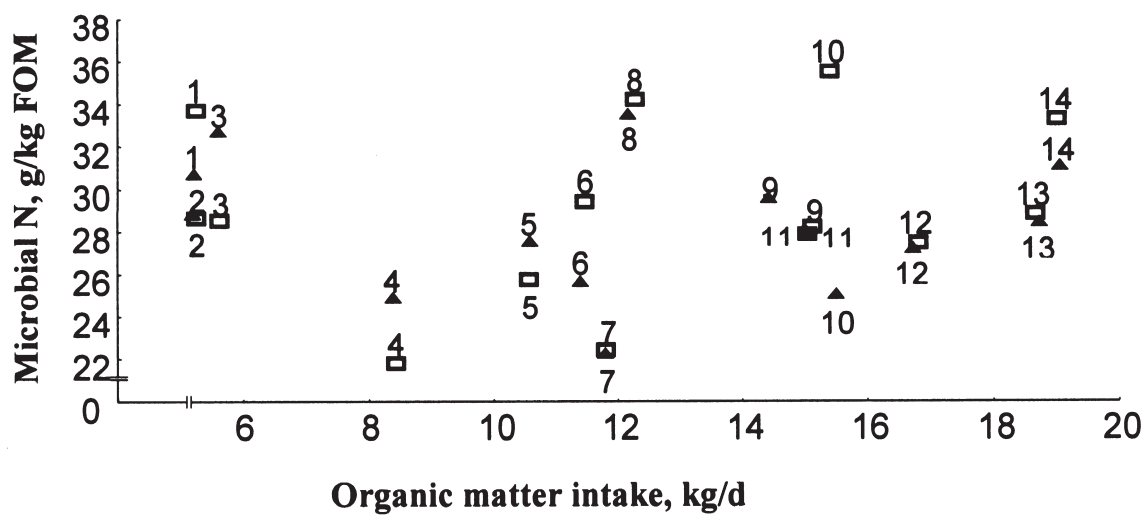

Figure 3. Efficiency of microbial protein synthesis in dependence on the organic matter intake, $\square$ Control period, $\boldsymbol{\Delta}$ Mycotoxin period, numbers denote individual animals

In accordance to Sniffen and Robinson (1987), who recalculated from the studies of Tamminga (1981) the lowest efficiency of microbial protein synthesis at about $10 \mathrm{~kg}$ of DM-intake, the efficiency was lowest at $9 \mathrm{~kg}$ organic matter intake and higher at intakes which were higher or lower.

Fusarium-contamination of the wheat did not affect the daily flow $(\mathrm{g} / \mathrm{d})$ of microbial protein $(\mathrm{P}=0.904)$.

Further analyses of duodenal digesta will give information about the metabolization of the mycotoxins in the rumen.

\section{REFERENCES}

Lebzien P., Paul C., 1997. Use of near infrared reflectance spectroscopy for the estimation of the microbial portion of non-ammonia-nitrogen in the duodenum of dairy cows. Anim. Feed Sci. Tech. 68, 225-233

Sniffen C.J., Robinson P.H., 1987. Protein and fiber digestion, passage and utilization in lactating cows. Microbial growth and flow as influenced by dietary manipulations. J. Dairy Sci. 70, 425441

Tamminga S., 1979. Protein degradation in the forestomachs of ruminants. J. Anim. Sci. 49, 16151630

Tyrell H.F., Moe P.W., 1975. Effect of intake on digestive efficiency. J. Dairy Sci. 58, 1151-1163 